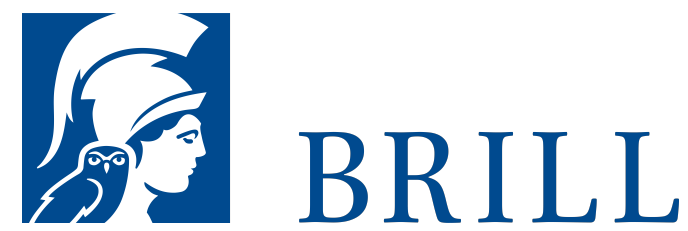

\title{
Europäische Reitermonumente
}

Ein Ritt durch die Geschichte Europas von Dante bis Napoleon

Author: Volker Hunecke

Reiterdenkmäler als Ausdruck herrscherlicher Pracht und herrscherlichen Willens durchziehen die europäische Geschichte. Mit dem Römischen Reich ging das Reitermonument in seiner vornehmsten Gestalt, dem überlebensgroßen ehernen Abbild, für lange Jahrhunderte unter. Im Italien der Renaissance wurde es wiedergeboren, die eisernen Herrscher bestiegen wieder ihre ehernen Rosse, zur Mehrung ihres Ruhmes. Reitermonumente breiteten sich von nun an als Symbole und wesentliche Bestandteile der Inszenierung von Fürstenmacht über ganz Europa aus. Volker Huneckes legt einen eindrucksvollen, reich bebilderten Überblick über alle künstlerisch, historisch, politisch und symbolgeschichtlich bemerkenswerten Reitermonumente vor, die in dem halben Jahrtausend zwischen Dante und Napoleon entstanden. Die glänzend geschriebene Darstellung ist gleichsam ein Ritt durch die europäische Geschichte, der sich von der Blüte der italienischen Stadtrepubliken bis zu den Massakern der Französischen Revolution an den ehernen Reitern der Monarchie erstreckt und der den Leser von Sizilien bis nach Skandinavien, von Lissabon bis nach Petersburg führt. Die eingehenden Analysen der verschiedenen Monumente lassen Hauptstationen der europäischen Geschichte im Spiegel der Kunst lebendig werden: das Freiheitsstreben der italienischen Kommunen, die Entstehung von Signorie und modernem Fürstenstaat; das Ringen...

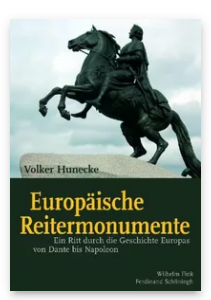

Pages: 342 Seiten, $123 \mathrm{~s} / \mathrm{w}$ Abb.

Language:

German

Subjects:

Cultural History,

Literature and

Cultural Studies

Publisher: Brill |

Fink

E-Book (PDF)

Released online:

13 Jan 2020

ISBN: 978-3-

8467-4425-3

List price

USD $\$ 84.00$

Hardback

Publication date:

17 Sep 2008

ISBN: $978-3^{-}$

7705-4425-7

List price

USD \$84.00 
For more information see brill.com

Order information: Order online at brill.com +44330 333 0049 | customerservices@brill.com Submission information: brill.com/authors

Titles published by Brill | Fink, Brill | mentis or Brill | Schöningh: +49(o)715413279216| brill@brocom.de 